\title{
Anti-erosion technology of potatoes irrigation on typical Chirchik-Angren valley serosemes
}

\author{
Dilshod Nazaraliev ${ }^{1}$, and Shamshodbek Akmalov ${ }^{1 *}$ \\ ${ }^{1}$ Tashkent Institute of Irrigation and Agricultural Mechanization Engineers, Hydraulic Department, \\ 100000 M.Ulugbek str. 39, Tashkent, Uzbekistan
}

\begin{abstract}
The article deals with the results of the analysis of long-term studies on the study of soil-protective, water efficiency technologies for the cultivation of crops on eroded soils. For the conditions of irrigated and erosion impacted typical loamy soils of a Chirchik-Angren valley, the law of a pliability of the typical loamy soils impacted by erosion is revealed depening on the form of furrows and the size of a jet. The optimum forms of the furrow and size of a jet are determined for condition of typical loamy soils at growing potatoes. The influence of the form of furrow on the contents of organic matter, total nitrogen, common phosphorus in a liquid and firm drain is established the losses of nutritious substances with a liquid and firm drain are revealed depending on elements of irrigation technology. The growth and development of the potatoes is studied. The economic efficiency is determined at cultivation of a potatoes on typical erosion demaged loamy soils.
\end{abstract}

\section{Introduction}

Potato is one of the most important and most common crops. According to its economic significance, potatoes are second only to grain and are rightly called second bread in the people.

Potato is the most important food, feed and technical crop. The nutritional value of potatoes is due to the high content of carbohydrates in it, good digestibility of proteins, a significant content of vitamin $\mathrm{C}$ and mineral salts of iron, calcium, etc. As a feed for animals, potatoes are used in the form of raw silo or steamed tubers, silo tops and industrial by-products - barbs, pulp.

Of great importance is the use of potatoes as raw materials for the alcohol, starch and syrup, dextrin, glucose, rubber and other industries. Along with other countries, in the republics of Central Asia, potatoes have exclusively food value.

The Action Strategy for 2017-2021, approved by decree of the President of the Republic of Uzbekistan, states that "... the use of intensive agricultural production methods, primarily the introduction of modern water and resource-saving technologies" is one of the most important tasks [1]. In this regard, conducting scientific research to improve the methods and application of anti-erosion measures, raising agricultural crops in lands subject to

\footnotetext{
* Corresponding author: shamshodbekjon@mail.ru
} 
erosion, is an effective way to radically increase and stabilize potato crops, improve their quality, maintain and increase soil fertility. [2,3,5,6,7,9,10,11,12,16,17,18,19,20].

Research on the development of scientifically based techniques and technology for irrigation of crops, in particular potatoes on lands subject to irrigation erosion is of great relevance, important economic and environmental importance $[10,14,17,18,19,20]$..

The aim of the research was to develop an anti-erosion technology for watering and obtaining high potato yields on typical serozem Chirchik - Angren Valley. Based on the objectives of the research objectives were:

- determination of the degree of compliance of the irrigated erosion typical gray soils, depending on the shape of the furrow and the size of the water jet;

- establishing the optimal number of zigzags in zigzag grooves;

- identification of the optimal dimensions of the irrigation stream in the furrow;

- a study of potato productivity depending on the shape of the furrow and the size of the stream on typical serozems subject to irrigation erosion;

- determination of the economic efficiency of anti-erosion irrigation technology on eroded soils.

\section{Methods and materials}

\subsection{Object of study}

The studies were carried out in the conditions of old irrigated typical serozems of Chirchik Angren Valley. According to soil conditions, the object is located in the belt of typical serozems. Due to the wavy surface of the relief, the soil cover here is very variegated, which is due to parent rocks, different depths of groundwater, various slopes and other factors.

The source of irrigation is the Chirchik River, the flow of which is regulated in the reservoir. Water for irrigation of crops is distributed along the channels of the on-farm irrigation network of various designs: channels with concrete lining and channel channels. Agricultural land development is characterized by a high coefficient of land use.

\subsection{Research Methodology}

The studies were carried out according to the methods developed at NIISSAVKH, NIIIVP and LLC UzGIP [4,6,16,17,18,19,20]. The small-scale experience is laid down in 3-fold repetition. The area of each plot is $280 \mathrm{~m} 2$, accounting $140 \mathrm{~m} 2$. The distance between the furrows is $70 \mathrm{~cm}$, the furrow length is $80-100 \mathrm{~m}$.

In the process of the study, the following observations, counts, measurements and definitions were made:

1. Accounting for irrigation and waste water using the weirs of Cipoletti with a threshold of $25 \mathrm{~cm}$ and Thompson with an angle of 900 .

2. Soil moisture was determined by the gravimetric method, the volumetric mass was determined cylindrically, the total duty cycle was determined by the calculation method, water permeability was determined by the frame method, and the smallest moisture capacity was determined by the poured sites method.

3. The mechanical composition of the soil is pipetted using sodium hexometophosphate.

4. The content in the soil of humus, total nitrogen, total phosphorus and potassium according to the method of UzNIIKh (1973).

5. Phenological observations - according to the methodology proposed by the Research Institute of Vegetable Melon and Potato. 
6. Mathematical processing of yield data by analysis of variance according to V. N. Peregudov (1981)

It should be noted that as a field erosion control measure, a $6.6 \mathrm{~cm}$ deep groove was used with transverse rollers cut with special tools that are hung on a KHU-4 cultivator instead of a hiller

\section{Results}

Before the start of the research, the soil sections of the full profile were laid in the experimental plot (Table 1).

Table 1. Morphological description of the soil stratum.

\begin{tabular}{|c|l|}
\hline Genetic layer, cm & \multicolumn{1}{c|}{ Morphological description } \\
\hline $0-30$ & $\begin{array}{l}\text { Gray, moist, from the top 0-5 cm dry, friable, lumpy-grained structure, } \\
\text { medium loamy, roots and crop residues are found, the transition is clear in } \\
\text { color. }\end{array}$ \\
\hline $30-60$ & $\begin{array}{l}\text { Light gray, moist, porous, medium loamy, granular, alfalfa root residues and } \\
\text { carbonate nodules are found, the transition is noticeable in density. }\end{array}$ \\
\hline $60-100$ & $\begin{array}{l}\text { Fawn with a grayish tint, less moist, of dense build, heavily loamy, fragile- } \\
\text { lumpy structure, carbonate mold and rare earthworm passages are found, the } \\
\text { transition is gradual. }\end{array}$ \\
\hline $100-150$ & $\begin{array}{l}\text { Fawn with a grayish tint, less moist, dense, heavily loamy, unclearly expressed } \\
\text { structure, carbonates in the form of nodules and white eyes are found, the } \\
\text { transition is gradual. }\end{array}$ \\
\hline
\end{tabular}

Soil fertility of the experimental plot. The irrigated gray soil of the experimental plot is poor in humus and nitrogen (Table 2). The data of the studies show that at the beginning of the studies in the arable layer the nutrient content was: humus $-1.017 \%$ by weight, total phosphorus $-0.108 \%$, total nitrogen $-0.097 \%$ and exchange potassium $340 \mathrm{mg} / \mathrm{kg}$ of soil.

Table 2. The content of humus, nitrogen, phosphorus and potassium in the soil, $\%$ by weight (start of research).

\begin{tabular}{|c|c|c|c|c|c|c|}
\hline \multirow{2}{*}{ Layer, cm } & \multicolumn{3}{|c|}{ Content, \% } & \multicolumn{3}{c|}{ Mobile forms, mg / kg. } \\
\cline { 2 - 7 } & Humus & Nitrogen N & Phosphorus P & NO$_{3}$ & $\mathbf{P}_{\mathbf{2}} \mathbf{O}_{\mathbf{5}}$ & $\mathbf{K}_{\mathbf{2}} \mathbf{O}$ \\
\hline $0-30$ & 1.017 & 0.097 & 0.108 & 11.0 & 31.6 & 340 \\
\hline $30-60$ & 0.442 & 0.038 & 0.075 & 8.4 & 22.8 & 320 \\
\hline $60-100$ & 0.322 & 0.032 & 0.065 & 8.4 & 18.8 & 315 \\
\hline $100-150$ & 0.265 & 0.027 & 0.065 & 8.4 & 11.0 & 300 \\
\hline
\end{tabular}

According to the content of humus, nitrogen, soils of the experimental plot are considered to be poorly provided, phosphorus - moderately provided, potassium is sufficiently provided. Thus, to obtain high and high-quality potato yields, high doses of nitrogen and moderate doses of phosphorus and potassium fertilizers are required.

The granulometric composition of the soil of the experimental plot was determined at the beginning of the research by pipetting using sodium hexometophosphate in samples 
taken from the soil section. The results of determining the granulometric composition are shown in Table 3.

Table 3. Granulometric composition of the soil of the experimental plot.

\begin{tabular}{|c|c|c|c|c|c|c|c|c|c|}
\hline \multirow[b]{2}{*}{$\begin{array}{c}\text { Layer, } \\
\mathrm{cm}\end{array}$} & \multicolumn{8}{|c|}{ Content $\%$ fractions in $\mathrm{mm}$ in size } & \multirow[b]{2}{*}{$\begin{array}{l}\text { Kachinsky } \\
\text { particle size } \\
\text { distribution }\end{array}$} \\
\hline & 辇 & 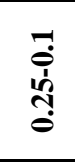 & $\frac{\stackrel{2}{0}}{\dot{1}}$ & 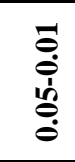 & 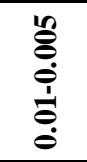 & 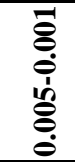 & $\begin{array}{l}\bar{\delta} \\
\stackrel{\theta}{\dot{\theta}}\end{array}$ & $\overline{\dot{\theta}}$ & \\
\hline $0-30$ & 1.81 & 0.88 & 19.7 & 32.6 & 10.52 & 17.9 & 16.5 & 44.9 & medium loamy \\
\hline $30-60$ & 0.86 & 0.84 & 15.3 & 41.2 & 2.26 & 22.3 & 17.1 & 41.1 & medium loamy \\
\hline $60-100$ & 0.30 & 0.92 & 6.86 & 45.0 & 13.6 & 24.0 & 9.18 & 46.7 & heavy loamy \\
\hline $100-150$ & 1.40 & 1.63 & 4.97 & 45.1 & 11.5 & 18.3 & 16.9 & 46.8 & heavy loamy \\
\hline
\end{tabular}

From table 3 it is seen that the soil of the experimental plot is medium loamy, homogeneous. The content of physical clay is: in the layer of $0-30 \mathrm{~cm}-44.9 \%$, in the layer of $30-60 \mathrm{~cm}-41.1 \%$, in the layer of $60-100 \mathrm{~cm}-46.7 \%$ and in the layer of $100-150 \mathrm{~cm}$ $46.8 \%$.

Volumetric mass of soil. At the test site, the bulk density was determined: at the beginning of the study, as well as at the beginning and end of the growing season of each year of research, with a depth of up to $1.0 \mathrm{~m}$ every $10 \mathrm{~cm}$. The results of determining the volumetric weight at the test site are shown in Table 4.

Table 4. The dynamics of changes in the volumetric mass of the soil of the experimental plot, $\mathrm{g} / \mathrm{cm} 3$.

\begin{tabular}{|c|c|c|c|c|c|c|}
\hline \multirow{2}{*}{ Layer, cm } & \multicolumn{5}{|c|}{ Years of study } \\
\cline { 2 - 7 } & \multicolumn{2}{|c|}{$\mathbf{2 0 1 4}$} & \multicolumn{2}{c|}{$\mathbf{2 0 1 5}$} & \multicolumn{2}{c|}{$\mathbf{2 0 1 6}$} \\
\cline { 2 - 7 } & $\begin{array}{c}\text { beginning of } \\
\text { vegetation }\end{array}$ & $\begin{array}{c}\text { end of } \\
\text { vegetation }\end{array}$ & $\begin{array}{c}\text { beginning } \\
\text { of } \\
\text { vegetation }\end{array}$ & $\begin{array}{c}\text { end of } \\
\text { vegetation }\end{array}$ & $\begin{array}{c}\text { beginning of } \\
\text { vegetation }\end{array}$ & $\begin{array}{c}\text { end of } \\
\text { vegetation }\end{array}$ \\
\hline $0-30$ & 1.30 & 1.32 & 1.31 & 1.33 & 1.29 & 1.31 \\
\hline $30-60$ & 1.36 & 1.37 & 1.37 & 1.38 & 1.37 & 1.38 \\
\hline $60-100$ & 1.38 & 1.39 & 1.38 & 1.39 & 1.39 & 1.40 \\
\hline
\end{tabular}

Under the influence of vegetation irrigation, mechanized processing, and other measures related to the cultivation of potatoes, compaction of soils occurs at the end of the growing season, i.e. increase in their bulk density. Soil compaction by years of growing potatoes in a layer of $0-30 \mathrm{~cm} ; 30-60 \mathrm{~cm}$ and $60-100 \mathrm{~cm}$ was $0.02 ; 0.01 ; 0.01 \mathrm{~g} / \mathrm{cm} 3$ (2014); $0.02 ; 0.01 ; 0.01 \mathrm{~g} / \mathrm{cm} 3$ (2015) and $0.02 ; 0.01 ; 0.01 \mathrm{~g} / \mathrm{cm} 3$ (2016)

It should be noted that in the arable layer of the soil, the bulk mass for growing potatoes is optimal, below it partially worsens.

Water permeability of soil. The water permeability of the soils of the experimental production site was determined at the beginning and end of the growing season using cylindrical circles. As you know, long-term cultivation of potatoes in the same irrigation plot partially affects the water-physical properties of soil. This is confirmed by the data on the determination of volumetric mass and water permeability of the soil of the experimental plot. 
So, over the years of growing potatoes, the water permeability of soil decreases by 0.04 $\mathrm{mm} / \min$ (2014) $0.04 \mathrm{~mm} / \min$ (2015) and $0.04 \mathrm{~mm} / \min$ (2016), respectively. (Table 5).

Table 5. Water permeability of the soil of the experimental plot.

\begin{tabular}{|c|c|c|c|c|c|c|c|c|c|c|c|}
\hline \multicolumn{12}{|c|}{ Years of research } \\
\hline \multicolumn{4}{|c|}{2014} & \multicolumn{4}{|c|}{2015} & \multicolumn{4}{|c|}{2016} \\
\hline \multicolumn{2}{|c|}{$\begin{array}{c}\text { The } \\
\text { beginning of } \\
\text { the } \\
\text { vegetation }\end{array}$} & \multicolumn{2}{|c|}{$\begin{array}{c}\text { The end of the } \\
\text { vegetation }\end{array}$} & \multicolumn{2}{|c|}{$\begin{array}{c}\text { The } \\
\text { beginning of } \\
\text { the } \\
\text { vegetation }\end{array}$} & \multicolumn{2}{|c|}{$\begin{array}{l}\text { The end of } \\
\text { the } \\
\text { vegetation }\end{array}$} & \multicolumn{2}{|c|}{$\begin{array}{l}\text { The } \\
\text { beginning of } \\
\text { the vegetation }\end{array}$} & \multicolumn{2}{|c|}{$\begin{array}{l}\text { The end of the } \\
\text { vegetation }\end{array}$} \\
\hline 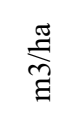 & 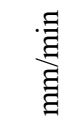 & 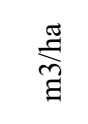 & 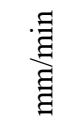 & 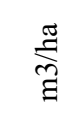 & 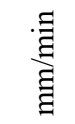 & $\stackrel{\Xi}{\overparen{\Xi}}$ & 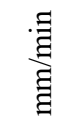 & $\sum_{\overparen{g}}^{\overparen{g}}$ & 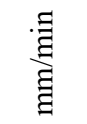 & 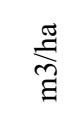 & 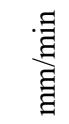 \\
\hline 1600 & 0.44 & 1460 & 0.40 & 1527 & 0.42 & 1366 & 0.38 & 1447 & 0.40 & 1293 & 0.36 \\
\hline
\end{tabular}

The smallest moisture capacity of soil. The smallest soil moisture capacity (HB) or maximum field moisture capacity (PPV) is one of the most important soil properties, on which the size of irrigation norms, irrigation rate, and determination of the timing of irrigation of crops depend. Its value depends mainly on the particle size distribution, agrochemical composition of the soil and the depth of the groundwater table. At the experimental production site, the smallest moisture capacity was determined at the beginning of the research using the flooded sites method.

Table 6. The smallest moisture capacity (HB) of the soil of the experimental plot, $\%$ by weight.

\begin{tabular}{|c|c|}
\hline Layer, $\mathbf{c m}$ & Least moisture capacity, $\%$ \\
\hline $0-30$ & 18.3 \\
\hline $0-50$ & 19.2 \\
\hline $0-70$ & 19.6 \\
\hline $0-100$ & 19.5 \\
\hline
\end{tabular}

The data in table 6 show that the lowest soil moisture capacity in the $0-30 \mathrm{~cm}$ layer was $18.3 \%$, in the $0-50 \mathrm{~cm}$ layer it was $19.2 \%$, in the $0-70 \mathrm{~cm}$ layer it was $19.6 \%$ and in the 0 $100 \mathrm{~cm}$ layer it was $19.5 \%$ by weight . A slight increase in humidity to the lower layers is associated with an increase in the mechanical composition, i.e. an increase in the amount of physical clay content. With increasing depth, soil moisture in the experimental plot decreases, which is associated with a deep occurrence of the groundwater level and the lack of groundwater recharge. The capillary rim of deeply located groundwater does not reach the root layer.

\section{Discussions}

Time to reach water. The travel time or travel speed of an irrigation jet over a dry furrow is one of the important elements of furrow irrigation technique. It mainly depends on the shape, size of the stream, water absorption capacity of the soil and its moisture.

It should be noted that the speed of water running along a dry furrow reflects only the first phrase of irrigation, at the time of the action of a high initial absorption rate, which leads to a low speed of water movement along the furrow. 
When watering potatoes in a straight (ordinary) furrow and a length of $80 \mathrm{~m}$ with an irrigation stream of $0.11 / \mathrm{s}$, the time to reach the irrigation stream during the growing season during the years of research varied from 254 to $408 \mathrm{~min}$. An increase in the irrigation stream to 0.151 / s contributed to a decrease in travel time from 225 to $376 \mathrm{~min}$, respectively, while an increase in the irrigation spray to $0.301 / \mathrm{s}$ contributed to a decrease in travel time from 221 to $287 \mathrm{~min}$, respectively.

Changing the shape of the furrow dramatically affects these indicators. So when watering potatoes along a zigzag groove (per 1 zigzag r.m. with an amplitude of $20 \mathrm{~cm}$ ) with an irrigation jet of $0.11 / \mathrm{s}$, the travel time of the irrigation stream varied from 319 to $458 \mathrm{~min}$, with an irrigation stream of 0.151 / s, respectively, from 300 to $392 \mathrm{~min}$.

When watering potatoes along a zigzag groove (per 1 meter 2 sinusoids with an amplitude of $20 \mathrm{~cm}$ ), respectively: from 433 to 496 ; from 383 to 466 and from 350 to 414 $\mathrm{min}$. An increase in the stream of water reduced the travel time from 14 to 40 , respectively; from 19 to 66 and from 30 to 50; from 82 to 83 minutes

The data obtained indicate that in the corresponding discharges of water in the furrow with an increase in the number of sinusoids, the time it takes for the water to travel along a zigzag furrow is longer than in a conventional furrow.

Potato irrigation regime. The correct determination of the optimal sizes of irrigation and irrigation norms is of great importance for the rational use of irrigation water $[5,8,17,18,19,20]$.

The value of the irrigation norm according to the experimental variants was determined by calculation, taking into account the water-physical properties of the soil, the depth of the moistened layer, the permissible moisture threshold according to the formula of S.N. Ryzhov (1948). The average potato irrigation regime over the years of research is shown in Table 7

Table 7. Potato Irrigation Regime.

\begin{tabular}{|c|c|c|c|c|}
\hline $\begin{array}{c}\text { Option } \\
\text { number }\end{array}$ & $\begin{array}{c}\text { Irrigation } \\
\text { scheme }\end{array}$ & Irrigation rate, $\mathbf{~ m}^{\mathbf{3}} \mathbf{h} \mathbf{h a}$. & $\begin{array}{c}\text { Inter-irrigation } \\
\text { period }\end{array}$ & Irrigation rate, $\mathbf{~ m}^{\mathbf{3}} / \mathbf{h a}$ \\
\hline 1 & $3-5$ & $726-799$ & $9-15$ & $6100-6170$ \\
\hline 2 & $3-5$ & $759-798$ & $9-15$ & $6200-6248$ \\
\hline 3 & $3-5$ & $719-775$ & $10-15$ & $5940-5970$ \\
\hline 4 & $2-6$ & $701-776$ & $10-16$ & $5810-6050$ \\
\hline 5 & $2-6$ & $719-784$ & $10-17$ & $5920-6070$ \\
\hline 6 & $2-6$ & $702-734$ & $11-17$ & $5650-5730$ \\
\hline 7 & $1-6$ & $771-796$ & $13-17$ & $5490-5500$ \\
\hline 8 & $1-6$ & $788-798$ & $13-18$ & $5556-5570$ \\
\hline 9 & $1-6$ & $786-795$ & $14-18$ & $5536-5550$ \\
\hline
\end{tabular}

In option 1, 2 and 3 where irrigation was carried out on a regular furrow, with a flow rate of $0.10 ; 0.15$ and $0.301 / \mathrm{s}$, the number of irrigations was 8 , with irrigation rates of 700 $800 \mathrm{~m} 3$ / ha and irrigation rates of 6100,6200 and $5970 \mathrm{~m} 3 /$ ha. Accordingly, the irrigation period was 9-15 days. In options 4, 5 and 6, where irrigation was carried out along a zigzag groove (one sinusoid per linear meter) with a flow rate of $0.10 ; 015 ; 0.301 / \mathrm{s}$ the number of irrigations was 8 , with irrigation rates of $700-800 \mathrm{~m} 3 /$ ha and irrigation rates of 5890.6000 and $5730 \mathrm{~m} 3$ / ha. The irrigation period varied between 10-17 days. In options 7, 8 and 9, where irrigation was carried out along a zigzag groove (two sinusoids per linear meter) with a flow rate of $0.10 ; 0.15$ and $0.301 / \mathrm{s}$ the number of irrigations was 7 , with irrigation rates of $700-800 \mathrm{~m} 3 /$ ha and irrigation rates of 5500,5570 and $5550 \mathrm{~m} 3 /$ ha, the irrigation period was 13-18 days. 


\subsection{Water balance of a potato field}

Based on our own research, we have compiled the water balance of the irrigated fields occupied by potatoes. (table 8).

Analysis of Table 8 shows that the average total water flow rate of the potato field is $5837 \mathrm{~m} 3$ / ha.

Table 8. Water balance of a potato field.

\begin{tabular}{|c|c|c|c|c|}
\hline \multirow{2}{*}{ Accounting Elements } & \multicolumn{3}{|c|}{ Years } & \multirow{2}{*}{$\begin{array}{l}\text { Average } \\
\text { for } 3 \text { year }\end{array}$} \\
\hline & 2014 & 2015 & 2016 & \\
\hline $\begin{array}{l}\text { The water supply in the layer } 0-100 \mathrm{~cm} \text { at the beginning } \\
\text { of the vegetation, } \mathrm{m}^{3} / \mathrm{ha}\end{array}$ & 2608 & 2567 & 2558 & 2578 \\
\hline $\begin{array}{c}\text { The water supply in the layer } 0-100 \mathrm{~cm} \text { at the end of the } \\
\text { vegetation, } \mathrm{m}^{3} / \mathrm{ha}\end{array}$ & 2335 & 2294 & 2282 & 2304 \\
\hline Use of moisture from moisture reserves in the soil, $\mathrm{m}^{3} /$ ha & 273 & 273 & 276 & 274 \\
\hline Precipitation, $\mathrm{m} 3$ / ha & - & - & - & - \\
\hline Irrigation water supplied, $\mathrm{m} 3$ / ha & 5570 & 5563 & 5556 & 5563 \\
\hline Total water consumption, $\mathrm{m} 3$ / ha & 5843 & 5836 & 5832 & 5837 \\
\hline $\begin{array}{l}\text { Used from soil moisture reserves, } \% \text { of total water } \\
\text { consumption }\end{array}$ & 4.7 & 4.7 & 4.7 & 4.7 \\
\hline Irrigation water used, $\%$ of total water consumption & 95.3 & 95.3 & 95.3 & 95.3 \\
\hline Harvest, $\mathrm{t} / \mathrm{ha}$ & 290 & 300 & 308 & 299 \\
\hline Total consumption of water per 1 centigrade of crop, $\mathrm{m}^{3}$ & 20.1 & 19.5 & 18.9 & 19.5 \\
\hline $\begin{array}{c}\text { Consumption of irrigation water per } 1 \text { centigrade of the } \\
\text { crop, } \mathrm{m}^{3}\end{array}$ & 19.2 & 18.5 & 18.0 & 18.6 \\
\hline
\end{tabular}

\subsection{The influence of the shape of the furrow and the flow rate of the irrigation jets on the potato crop}

The results of our studies showed that under the same conditions (the steepness of the slope, the size of the stream of water and the norms of applying mineral fertilizers) on eroded soils, the potato crop depends on the shape of the irrigation furrow (table 9). So, the average potato harvest for 3 years when irrigated with ordinary furrows, with a stream of $0.11 / \mathrm{s}$, was $226 \mathrm{~kg}$ / ha, with zigzag furrows (1 sinusoid and 2 sinusoid per 1 1.m. with an amplitude of $20 \mathrm{~cm}$ ), respectively, 237 and $259 \mathrm{~kg} / \mathrm{ha}$.

With jets of 0.15 and $0.301 / \mathrm{s}$ in the corresponding furrows, the yield, respectively, was: 237; 248; 299 and 223; 235; $268 \mathrm{~kg}$ / ha.

Thus, when watering potatoes along a zigzag furrow with a flow rate of $0.151 / \mathrm{s}(2$ sinusoids per $1 \mathrm{~m} . \mathrm{m}$. amplitude of $20 \mathrm{~cm}$ ), the water regime improves and the processes of soil irrigation erosion are reduced, which contributes to better growth and development of plants, as well as an increase in potato yield. 
Table 9. The dependence of the potato crop on the shape of the furrow and the size of the irrigation stream.

\begin{tabular}{|c|c|c|c|c|}
\hline \multirow{2}{*}{$\begin{array}{c}\text { No } \\
\text { Options }\end{array}$} & \multirow{2}{*}{ Discharge, $\mathbf{1} / \mathbf{s}$} & \multicolumn{3}{|c|}{ Productivity, sen/ha } \\
\cline { 3 - 5 } & 0.10 & $\mathbf{2 0 1 4}$ & $\mathbf{2 0 1 5}$ & $\mathbf{2 0 1 6}$ \\
\hline 1 & 0.15 & 212 & 220 & 235 \\
\hline 2 & 0.30 & 228 & 240 & 244 \\
\hline 3 & 0.10 & 210 & 230 & 230 \\
\hline 4 & 0.15 & 240 & 240 & 248 \\
\hline 5 & 0.30 & 220 & 250 & 255 \\
\hline 6 & 0.10 & 250 & 240 & 246 \\
\hline 7 & 0.15 & 290 & 280 & 286 \\
\hline 8 & 0.30 & 240 & 300 & 308 \\
\hline 9 & & & 280 & 284 \\
\hline
\end{tabular}

\subsection{Economic efficiency}

The calculation of the economic efficiency of growing potatoes with various forms of furrows and the magnitude of the irrigation stream of potatoes was carried out in accordance with current standards and pay systems adopted in the Republic of Uzbekistan. When calculating the economic efficiency, we took into account the costs (in sums) for agricultural practices, for irrigation and harvesting per 1 ha of sowing. Taking into account the selling value of potatoes, the size of the conditional net income from 1 ha has been established.

The most effective option was 8 , where irrigation was carried out along a zigzag groove ( 2 sinusoids per 1 meter). Contingent net income in this option amounted to 1053360 sum / ha.

\section{Conclusion}

1. The highest potato yield with relatively minimal soil erosion was obtained in option 8 , where irrigation was carried out according to scheme $1-6$, with norms of $700-800 \mathrm{~m}^{3} /$ ha, with an irrigation norm of $5600 \mathrm{~m}^{3} /$ ha, along a zigzag groove (2 sinusoids per $1 \mathrm{~m}$.), preirrigation soil moisture was maintained at a level of $70-80 \% \mathrm{HB}$.

2. In the best case, the irrigation norm of the potato field is $5837 \mathrm{~m}^{3} /$ ha, of which 274 $\mathrm{m} 3$ / ha was used from the moisture reserves in the soil, $5563 \mathrm{~m}^{3} /$ ha, the irrigation norm, irrigation water consumption per 1 centner. harvest amounted to $18.6 \mathrm{~m}^{3}$.

3 . When watering potatoes on a zigzag groove ( 2 sinusoids per 1 running meter) with a flow rate of $0.151 / \mathrm{s}$ and an irrigation rate of $700-800 \mathrm{~m}^{3} /$ ha according to scheme $1-6$, an irrigation rate of $5600 \mathrm{~m}^{3}$ / ha, the largest conditional net income - $1053360 \mathrm{sum} /$ ha.

\section{References}

1. A. Arifjanov, L. Samiev, Sh. Akmalov, International Journal of Innovative Technology and Exploring Engineering (IJITEE) ISSN: 2278-3075, 9 (1), (2019)

2. A. Arifjanov, M Otaxonov, L. Samiev, Sh. Akmalov E3S Web of Conferences, 97, 05039 (2019)

3. A. Arifjanov, Sh. Akmalov, I. Akhmedov, IOP Conf. Series: Earth and Environmental Science, 403, 012155 (2019) 
4. A. Arifjanov, K. Rakhimov, D. Abduraimova, Sh. Akmalov, IOP Conf. Series: Earth and Environmental Science, 403, 012154 (2019)

5. A. Arifjanov, L. Samiev, T. Apakhodjaeva, Sh. Akmalov, IOP Conf. Series: Earth and Environmental Science, 403, 012153 (2019)

6. A. Arifjanov, T. Apakhodjaeva, Sh. Akmalov, International Conference on Information Science and Communication Technologies (ICISCT), 1-4 (2019)

7. T. Abdugalimov, K.B. Balgabekov, Bulletin of agricultural science of Kazakhstan, 7, 45-46 (1980)

8. T.E. Astanakulov, D.T. Abdukarimov, Scientific worksofther, 115, 20-30 (1985)

9. B. Sh. Akhmedov, Metodы prognozirovaniya irrigatsionnoy erozii pochv i opredeleniya optimalnыx parametrov protivoerozionnыx borozd na sklonovыx zemlyax [Methods of Forecasting Irrigation Erosion of Soils and Determination of Optimal Parameters of Anti-Erosion Furrows on Sloping Lands] Autor.cand.diss, (Tashkent, 1988)

10. V.M. Bauchidze, Irrigation in mountain conditions (Kolos, Moscow, 1981)

11. A.M. Zerbaliev, Vliyanie texniki borozdovogo poliva na eroziyu pochv [ Influence of furrow irrigation equipment on soil erosion [Increase in the efficiency of irrigated land use and progressive irrigation of technical irrigation] (Novocherkassk, 1980)

12. R.S. Kabilov, Agrotexnicheskie sposobi zashiti pochv ot irrigatsionnoy erozii i puti povisheniya plodoriya pochv na sklonovix zemlyax pri oroshenii [Agrotechnical methods of soil protection from irrigation erosion and ways to increase the soil fertility on sloping lands during irrigation [Soil-erosion processes and measures to combat soil erosion] (Donish, Dushanbe, 1991)

13. K.M. Mirzazhanov, Soil science, 2, 122-125 (1985)

14. M. Khamidov, D. Nazaraliev, A. Hamidov, International journal of geology, 1(3), 1719 (2009)

15. Generalnaya sxema protivoerozionnix meropriyatiy $\mathrm{v}$ Uzbekistane [The general scheme of anti-erosion measures in Uzbekistan] (Tashkent, 1981)

16. D.V. Nazaraliev, Y. Daribayev, Growth and development of potatoes depending on the shape and flow of the irrigation stream, 5-6, 22-23 (2001)

17. D.V. Nazaraliev, International Conference "Problems of water resources management and operation of irrigation and drainage systems in the context of water user associations", 12, 119-122 (2002)

18. N.K. Nurmatov, Texnologiya orosheniya selskoxozyaystvennix kultur na sklonovix zemlyax Tadjikistana [Irrigation technology of agricultural crops on the sloping lands of Tajikistan] / Abstract. on the doctoral degree of Doctor of Science, (Tashkent. 1992)

19. Sh.N. Nurmatov, G.N. Abdalova .J. Cottonand Wheat., o3, 7-9 (2001)

20. Sh. Nurmatov, Teoreticheskie osnovi prognozirovaniya irrigatsionnoy erozii pochv i metodi borbi s ney [Theoretical Foundations of Forecasting Irrigation Erosion of Soils and Methods of Fighting it] Autor.doc.diss. (Tashkent, 1993) 